УДК 351.741:342.7

DOI https://doi.org/10.32849/2663-5313/2021.6.22

\title{
Андрій Танъко,
}

канд. юрид.наук,

докторант відділу організаціӥ освітньо-наукової підготовки

Харківського начіонального університету внутрішніх справ

\section{МОРАЛЬНО-ПРАВОВА ГОТОВНІСТЬ ПРАЦІВНИКІВ ОРГАНІВ НАЦІОНАЛЬНОЇ ПОЛІЩІЇ УКРАЇНИ ДО ВИРІШЕННЯ ПРОБЛЕМ ГРОМАДЯН У СФЕРІ ЗАБЕЗПЕЧЕННЯ ПРАВ І СВОБОД ЛЮДИНИ}

У статті обгрунтовано необхідність удосконалення морально-правової готовності праиівників органів Національної полічії України до роботи з громадянами в контексті підвищення вимог до рівня професійної компетентності працівників служби Національної поліиії як важливого суб'єкта захисту прав і свобод людини в Україні.

На основі аналізу законодавчих актів, юридиної літератури доведено, що розгляд процесу формування морально-правової готовності пращівників органів полічії до вирішення проблем громадян у сфері забезпечення прав і свобод людини має відбуватися комплексно, у контексті висвітлення сучасних тенденцій розвитку правоохоронної сфери в Україні, нових иілей і завдань виховної роботи зі слухачами, курсантами та службовим складом органів полічій в процесі первинної професійної підготовки, післядипломної освіти, службової підготовки, що забезпечить цілісність висвітлення порушеної проблеми, дасть змогу простежити єдність і підпорядкованість загальній виховній меті різних видів підготовки працівників Національної полічії України.

Установлено, що процес формування морально-правової готовності працівників органів поліиії до правоохоронної роботи з громадянами має подвійну спрямованість, забезпечуючи, з одного боку, особистісний розвиток правоохорония, з іншого - розширюючи та збагачуючи правові знання й досвід професійно-правої взаємодії з громадою. Мета підготовки полічейського до вирішення правозахисних проблем громадян полягає у створенні умов і режиму освіти й самонавчання фахівия, які повсякчас забезпечували б збагачення морально-правових знань, формування гуманістичних особистісних иінностей у професійній сфері, засвоєння ціннісного ставлення до професії правоохорония загалом і такого виду діяльності, як взаємодія з населенням; підвищення професійної мотивації і здатності до втілення високих моральних настанов у професійній діяльності.

Розкрито адміністративно-регулящійні й особистісно-формувальні завдання підготовки прачівників органів Національної полічій України, обгрунтовано зміст виховного процесу, що складається з основних виховних напрямів (громадянсько-патріотичний, морально-иіннісний, політичний, правовий, фізичний), які забезпечують той чи інший аспект різнобічного формування морально-правової готовності правоохорониів до роботи у сфері захисту прав і свобод громадян.

Ключові слова: права і свободи людини, робота в громаді, морально-правова готовність, працівники поліції.

Постановка проблеми. Сьогодні робота правоохоронних органів із захисту прав і свобод людини стає ближчою до реальних потреб населення, орієнтованою на тісну співпрацю 3 громадою, створення та підтримку в суспільстві комфортних соціально-правових умов для життя людини, безперешкодне забезпечення іï інформаційно-правовим супроводом, у тому числі в режимі онлайн-консультування та в інших видах медійної активності служби поліції, своєчасне отримання кожною конкретною людиною правової підтримки й допомоги та всього спектру відповідних поліцейських послуг, необхідних для реалізації своїх прав, свобод і законних інтересів. Це пов'язано й із тим, що концептуальні засади адміністративно-правового регулювання діяльності державних інституцій з правового захисту людини в Україні значно змінюються, створюються нові структури правового захисту населення, а традиційно наявні докорінно реформуються, як, наприклад, перетворення служби міліції в інноваційну за своїми правоохоронними функціями Національну поліцію України.

Ураховуючи європейський досвід організації взаємодії поліції з громадою, 
вітчизняним правоохоронцям необхідно системно здобувати й удосконалювати навички роботи в межах моделі партнерської поліцейської діяльності (Community Policing), яка активно впроваджується в Україні. У межах цієї моделі саме органи поліції та їх працівники на затверджених у державі правових засадах здійснюють упорядкування й організацію конкретного суспільного простору, беруть на себе координуючу функцію в запобіганні проблемам і подоланні проблем, пов'язаних із підтриманням правопорядку й безпеки громадян у середовищі їх перебування, за місцем проживання, у територіальній громаді, організують взаємодію між населенням і різними суб'єктами правового захисту, володіючи необхідними компетентностями та повноваженнями.

Відповідно, вітчизняні правоохоронці важливі суб'єкти діяльності із захисту прав і свобод людини в Україні - у процесі поліцейської діяльності мають виконувати цілу низку пов'язаних із професійною комунікацією інноваційних за своєю природою завдань, вирішення яких потребує набуття нових правових знань, умінь, навичок, розвитку особистісних характеристик, отримання сучасних професійних компетентностей, що забезпечують високий рівень особистіснопрофесійної готовності фахівців до ефективної роботи з громадянами.

Зважаючи на велику роль суб'єктивного чинника в роботі поліції з вирішення правозахисних проблем громадян, особливо гостро постає питання формування особистісної готовності працівників поліції до роботи в правоохоронних органах, що, відповідно до статті 72 Закону України «Про Національну поліцію», може здійснюватися як під час первинної професійної підготовки, підготовки в закладах вищої освіти зі специфічними умовами навчання, так і в системі післядипломної освіти (спеціалізація; перепідготовка; підвищення кваліфікації; стажування) й у процесі службової підготовки.

Сучасні вчені (О. Балинська, Р. Благута, О. Безпалова, В. Венедиктов, Л. Гуменюк, I. Зозуля, 3. Кісіль М. Коваль, 3. Ковальчук, О. Ковбич, В. Лапшина, В. Медведєв, О. Музичук, І. Нестерова, В. Середа, О. Скакун, С. Сливка, О. Тімченко В. Христенко, О. Шмоткін та інші) значну науково-практичну увагу надають проблемі формування особистісно-професійної готовності працівників Національної поліції до роботи у сфері забезпечення праві і свобод людини, що актуалізується в контексті реформування правоохоронних органів України, інтеграції європейського правозахисного досвіду.
У дослідженнях вітчизняних науковців (Н. Андреєв, В. Андросюк, О. Бандурка, В. Барко, Я. Бондаренко, С. Бочарова, А. Буданов, В. Васильєв, С. Запорожцева, О. Землянська, В. Коновалова, М. Котелюх, О. Корнєв, М. Логочев, А. Лігоцький, О. Петленко, В. Синьов, О. Столяренко, О. Тімченко, Д. Швець, Г. Яворська та інші) грунтовно вивчаються питання особистіснопсихологічної й морально-правової готовності працівників поліції як основи компетентності у вирішенні сучасних завдань службової діяльності в умовах нових професійних викликів.

Аналізуючи стан дослідження порушеної проблеми, підкреслимо, що морально-правова готовність працівників органів Національної поліції України до вирішення соціально-правових проблем громадян є однією з найвагоміших передумов створення системи результативного адміністративно-правового регулювання діяльності правоохоронних органів і суттєвим кроком практичного втілення в суспільне функціонування моделі сервісної поліції, робота якої побудована відповідно до положень міжнародних правозахисних документів щодо законності й правопорядку, верховенства права та рівного доступу всіх громадян без винятку до отримання повного спектру поліцейських послуг. Зважаючи на зазначене, проблема вдосконалення цього аспекту підготовки працівників поліції до вирішення численних завдань сьогодення, пов'язаних із забезпеченням прав і свобод людини, посідає надзвичайно важливе місце в роботі Національної поліції України.

Метою статті є обгрунтування необхідності вдосконалення морально-правової готовності працівників органів Національної поліції України до роботи з громадянами як основи підвищення рівня їхньої компетентності у сфері забезпечення прав і свобод людини, розкриття сутності й складників такої готовності.

\section{Завдання дослідження:}

- схарактеризувати сутність процесу формування морально-правової готовності працівників органів поліції до роботи з громадянами у сфері забезпечення прав і свобод людини, розкрити основні вимоги до особистісної компетентності поліцейського в умовах співпраці із громадою та надання поліцейських послуг населенню;

- на основі аналізу законодавчої й теоретично-методичної бази підготовки працівників поліції висвітлити загальну виховну мету процесу формування морально-правової готовності працівників органів поліції до правоохоронної роботи з громадянами; 
- визначити організаційні та виховні завдання підготовки працівників органів Національної поліції України, що забезпечують формування морально-правової готовності до роботи з громадянами;

- висвітлити напрями формування різних аспектів морально-правової готовності фахівців до побудови конструктивних стосунків поліції та громади.

Наукова новизна дослідження. На основі аналізу юридичної літератури та законодавчих актів України досліджено проблему формування морально-правової готовності працівників органів поліції до роботи з громадянами у сфері забезпечення прав і свобод людини; висвітлено правове підгрунтя, мету, завдання, зміст формування морально-правової готовності поліцейських до вирішення завдань правового забезпечення громадян України.

Виклад основного матеріалу. Потреби сьогодення зумовлюють усе більшу гуманізацію процесу правового забезпечення людини в Україні, орієнтують працівників поліції на розвиток комунікативної й моральної сфер особистості, формування емпатії, готовності вислухати людину та прийти їй на допомогу. Відповідно, сьогодні потреба в професійнопосадовому розвитку персоналу правоохоронних органів має не абстрактну, а суто конкретну природу і спрямована на вирішення реальних завдань, одним із найважливіших із яких є посилення індивідуального характеру професійної мотивації осіб рядового й начальницького складу в ситуації суттєвої зміни професійних умов [1, с. 84-85].

Наголошуючи на необхідності дослідження питання формування морально-правової готовності працівників поліції до продуктивної роботи з громадою, зазначимо, що до роботи в новій поліції можуть бути залучені повнолітні особи з інших професійних галузей, як і фахівці, які постійно працювали в інших підрозділах системи МВС, за умови проходження ними перекваліфікації. Як зазначає сучасна дослідниця Я. Посохова, усіх їх об'єднує перспективна місія опанування новим «прозорим» підходом до правової взаємодії з населенням, прагнення знайти себе в правоохоронній діяльності, розвиватися і професійно самовдосконалюватися, усі вони знаходяться в процесі професійного становлення. Причому для більшості з них мова йде про вторинну професіоналізацію, відповідно, про ускладнення процесів формування нової професійної ідентичності [2, с. 3]. Ми згодні з висновком дослідниці, що від успішності процесів правової та професійної ідентифікації працівників поліції сьогодні залежить ефективність реформування правоохоронної галузі України загалом.
Розглядаючи Закон України «Про Національну поліцію» [9], можемо зробити акцент на тому, що на сучасному етапі розвитку правоохоронної сфери суспільства поліцейським необхідно систематично підвищувати рівень особистісної готовності в напрямі реалізації ключової мети роботи органів поліції - забезпечення прав і свобод людини, захисту інтересів суспільства й держави, протидії злочинності та підтримки національної безпеки України, адже така діяльність грунтується на пріоритеті законності дій суб'єктів правового захисту, потребуючи від них значної комунікативно-правової культури, зміцнення службової дисципліни та самодисципліни, посилення контролю й відповідальності працівників органів поліції, що, у свою чергу, потребує регулярного перегляду основних підходів до професійної підготовки поліцейських, удосконалення їхніх морально-правових якостей і характеристик [3, с. 123].

Очевидно, що кардинальна зміна вимог до якості та рівня особистісної й професійної готовності поліцейських, процесу їхньої підготовки зумовила суттєву турботу законодавців і психологів стосовно питань адміністративно-правового забезпечення, оновлення змісту й форм організації освітньої та виховної роботи $з$ поліцейськими як потенційними суб'єктами забезпечення прав і свобод людини. Як підкреслює Я. Посохова, система правоохоронних органів України, яка зазнала за останній час серйозних перетворень, надала дослідникам практично унікальну можливість спостерігати в режимі реального часу процеси становлення таких феноменів, як професійна свідомість, професійна ідентичність, професійна компетентність у людей, значна частина яких до недавнього часу жодного відношення до правоохоронної системи не мала [2, с. 3].

Вивчення праць учених (О. Бандурка, В. Кім, Д. Кравцов, А. Маркова, Я. Посохова, I. Семенюкта та інші) щодо формування особистісної готовності працівників поліції до роботи в правоохоронних органах дає підстави для важливих узагальнень, що становлять підгрунтя для вдосконалення змісту, форм і методів виховної роботи 3 підвищення рівня морально-правової готовності суб'єктів забезпечення прав і свобод людини в процесі первинної професійної підготовки, підготовки в закладах вищої освіти зі специфічними умовами навчання, післядипломної освіти, службової підготовки. Серед таких узагальнень, по-перше, те, що специфіка виховної роботи з працівниками поліції зумовлюється особливостями сучасного стану світового й вітчизняного освітнього 
простору, визначається законодавчими актами України про освіту, вищу освіту, відомчу освіту в системі МВС України, але, крім того, здійснюється з урахуванням соціально-психологічних характеристик сучасної молоді й студентства.

По-друге, система виховання працівників поліції та курсантів спрямована сьогодні насамперед на оволодіння загальнолюдськими й національними гуманістичними та моральними цінностями й етичними нормами суспільства як основою вироблення морально-правових стандартів професійної діяльності, особистісних оцінок і вчинків, ієрархії морально-етичних властивостей особистості.

По-третє, можемо стверджувати, що одним із найважливіших напрямів організації діяльності з поліцейськими та курсантами в системі, як первинної професійної, так і службової й інших видів підготовки, $\epsilon$ цілеспрямоване та планомірне формування в суб'єктів забезпечення прав і свобод людини морально-правової готовності до служіння суспільству й державі.

По-четверте, уважаємо, що робота зі співробітниками поліції й курсантами, спрямована на підвищення рівня їхньої морально-правової готовності, повинна бути безпосередньо взаємопов'язаною 3 реальною практикою діяльності із забезпечення прав і свобод громадян, її зміст має відображати наявні потреби та нагальні проблеми населення України, а в ході такої підготовки необхідно прагнути навчити слухачів будувати свою звичну поведінку на досить надійних загальнолюдських цінностях.

По-п'яте, необхідно враховувати, що результат виховної роботи 3 формування морально-правової готовності поліцейських до роботи із населенням у питаннях забезпечення прав і свобод людини відображає на індивідуально-особистісному рівні функціональну сукупність їхніх морально-етичних особистісних характеристик і професійноправових знань і вмінь, забезпечує зростання впевненості у своїх силах, спонукає до активної життєвої позиції, оптимістичного сприйняття професійної діяльності, сприяє набуттю власної гідності й поваги до гідності інших, професійної самоідентичності, формуванню системи гуманістичних цінностей правоохоронців.

На підтвердження наведемо висловлювання В. Литвина, який зазначає, що в ході професіоналізації поліцейського основним результатом є система індивідуально сформованих за час професійної підготовки, перепідготовки та практичної службової діяльності професійних знань, умінь, навичок, які становлять інтровертні механізми виконання службових завдань [4, с. 278-279].

Грунтуючись на зазначених положеннях, підкреслимо, що розгляд процесу формування морально-правової готовності суб'єктів забезпечення прав і свобод людини в системі підготовки працівників правоохоронних органів має відбуватися комплексно, передбачаючи аналіз цілей, завдань і принципів, змісту, форм і методів роботи виховної роботи з поліцейськими та курсантами/слухачами в різних освітніх і професійних осередках, що забезпечить цілісність розробки всіх складників процесу професіоналізації поліцейських, загальну регламентованість їхньої діяльності й підпорядкування єдиній виховній меті.

Відзначимо, що, на нашу думку, розгляд процесу формування морально-правової готовності як такого, що наскрізно пронизує ввесь тривалий і неодноманітний процес професіоналізації суб'єктів забезпечення прав і свобод людини, є присутнім у всіх їі ланках: дійсно, є найбільш оптимальним і забезпечує надійний результат виховної роботи щодо оновлення й гуманізації поліцейської діяльності в умовах докорінного реформування системи МВС. Такий погляд корелює зі зробленим нами висновком, що, зважаючи на змінювані умови роботи органів поліції, професіоналізація їх працівників характеризується як безперервний процес становлення особистості фахівця та подальшого розвитку професійної компетентності (професіоналізму), що розпочинається з моменту професійної підготовки поліцейського, вступу його на службу та припиняється лише із завершенням трудової діяльності.

Разом із цим необхідно підкреслити, що, розробляючи питання формування морально-правової готовності працівників органів Національної поліції України до вирішення проблем громадян у сфері забезпечення прав і свобод людини, варто враховувати, що різні осередки, різні ланки професійної підготовки поліцейських, відображені в Законі України «Про Національну поліцію», мають свою специфіку.

Так, первинну професійну підготовку здійснюють вищі навчальні заклади МВС зі специфічними умовами навчання й установи (заклади) Національної поліції, що діють для забезпечення організації відповідної спеціальної підготовки поліцейських, уперше прийнятих на службу в поліції, а також підвищення кваліфікації й перепідготовки молодшого складу поліції, проведення окремих видів службової підготовки поліцейських [10]. Заклади вищої освіти зі специфічними умовами навчання $є$ освіт- 
німи осередками, де відбувається підготовка кадрів для Міністерства внутрішніх справ України й Національної поліції України; до цієї категорії належить і вищий військового навчальний заклад Національної гвардії України [11].

Підрозділи післядипломної освіти створені для спеціалізованого вдосконалення освіти та професійної підготовки працівників органів внутрішніх справ шляхом поглиблення, розширення й оновлення їхніх професійних знань, умінь і навичок або отримання іншої спеціальності на основі здобутого раніше освітньо-кваліфікаційного рівня та практичного досвіду [12].

Сутність службової підготовки висвітлено в Законі України «Про Національну поліцію» в контексті системного впорядкування заходів, спрямованих на закріплення та оновлення необхідних знань, умінь і навичок працівника поліції з урахуванням оперативної обстановки, специфіки та профілю його оперативно-службової діяльності [9].

Уважаємо, що при розробці спільної для всіх цих структур освіти поліцейських виховної мети в контексті досліджуваної проблеми необхідно враховувати думку В. Сокуренка, що в умовах реформування системи МВС України, розбудови діяльності правоохоронних органів нашої держави на особливу увагу заслуговують питання, пов'язані зі здійсненням належної професійної підготовки ï особового складу. Перехід діяльності вітчизняних силових структур, у тому числі й Національної поліції України, до Свропейських стандартів навчання зумовлює перегляд змісту навчання працівників поліції, які виконують професійні обов'язки, потребуе від усього особового складу Національної поліції володіння сучасними професійними знаннями та навичками щодо протидії злочинності, груповим порушенням публічної безпеки й порядку, виявлення та знешкодження організованих злочинних груп тощо [5, с. 8]. Відповідно, при всьому врахуванні специфіки і традицій кожного осередку освіти працівників правоохоронних органів спільним універсальним завданням залишається виховання фахівця, який має глибокі професійні знання та здатний ставити особистісно значущі цілі, що сприяють розвиткові й зміцненню правоохоронної держави.

До завдань виховання особистості поліцейського належать формування й розвиток його світоглядної, морально-ціннісної, політико-правової, фізичної культури, високого гуманізму, патріотичних якостей, дисциплінованості, активності, стимулювання зусиль перемінного складу до саморозвитку й самовиховання, духовного пошуку, творчого став- лення до навчання. Зважаючи на це, можемо стверджувати, що розвитку професійного та морального складників особистості поліцейського надається пріоритет у визначенні спрямованості виховної роботи структур, що здійснюють підготовку правоохоронців.

На основі аналізу нормативних документів щодо організації виховної роботи з курсантами у закладах освіти зі специфічними умовами навчання С. Яровий також зазначає, що об'єктивно обумовлений, цілеспрямований, планомірний, систематичний виховний вплив на свідомість і поведінку правоохоронців має передусім спрямовуватися на прищеплення, становлення й розвиток у них необхідних для подальшої практичної діяльності морально-етичних якостей [6, с. 198].

Зважаючи на це, підкреслимо, що мета виховної роботи 3 формування моральноправової готовності поліцейських полягає в цілеспрямованому формуванні правосвідомості, загальної культури та особистісних якостей майбутнього працівника органів внутрішніх справ України відповідно до загальнолюдських морально-етичних норм, а також вимог служби.

Загальна мета визначає спрямованість виховної роботи з формування моральноправової готовності поліцейських і впорядковує інші складники виховного процесу, об'єднує різноманітні форми та методи діяльності. В. Ортинський зазначає, що меті виховання підпорядковано все: зміст, організація, форми й методи, тому проблема визначення мети виховання є важливою в науці [7, с. 48].

Підкреслимо подвійну спрямованість виховної роботи з працівниками поліції, оскільки вона покликана забезпечити як моральний розвиток особистості правоохоронця, так і розширення та збагачення правових знань і досвіду їхньої професійно-правої діяльності. Обидва ці аспекти виховання $€$ конче потрібними, оскільки лише в комплексі забезпечують морально-правову готовність працівників органів Національної поліції України до вирішення проблем громадян у сфері забезпечення прав і свобод людини.

Проте поєднання професійно-правового та морального аспектів у реалізації мети виховної роботи з працівниками поліції не $€$ механічним, оскільки лише їх гармонійне взаємопроникнення та взаємопотенціювання забезпечує розвиток особистості правоохоронця загалом, де набуття правової грамотності й розвиток моральних якостей особистості відбуваються в певному взаємопідпорядкуванні.

Відзначимо, що в досліджуваному контексті для конкретизації мети діяльності необхідно її прогностичне зіставлення з май- 
бутнім результатом. Ми згодні з думкою М. Ануфрієва, О. Бандурки, О. Ярмиша, згідно з якою результат виховання виявляється в ставленні особистості до інших людей, до праці, до себе самої через вчинки, поведінку, у спілкуванні, у процесі праці, а його досягнення забезпечується включенням поліцейських у реальну діяльність із забезпечення прав і свобод людини в умовах конкретного органу поліції не лише службової, а й волонтерської, суспільно корисної, спортивно-оздоровчої та деяких інших видів діяльності, яка здійснюється в громаді та ініціюється громадянами, спонукаючи працівників поліції розвивати, удосконалювати або формувати необхідні особистісні якості й характеристики. Як бачимо, визначена мета забезпечує досягнення тієї складової частини результату виховання працівників поліції, яка пов'язана з формуванням їхньої морально-правової готовності (моральноправових знань, ієрархії правових і моральних цінностей у професійній сфері, ціннісного ставлення до професії правоохоронця; здатності до застосування моральних норм у професійній діяльності тощо), а тому $є$ педагогічно обгрунтованою та доцільною.

Конкретизація обгрунтованої мети відбувається шляхом розробки відповідних їй і змісту поліцейської діяльності завдань, що можуть бути розподілені на дві групи: адміністративно-регуляційні й особистісно-формувальні. Перша група завдань спрямована на вирішення питань адміністративно-правового регулювання процесу організації виховного впливу на службовий склад органів поліції. Найважливішим із завдань, безумовно, є підготовка всіх суб'єктів підготовки працівників поліції до роботи з формування морально-правової готовності на основі глибокого розуміння наявних умов, можливостей і шляхів спільної, узгодженої реалізації такої діяльності, оцінки реального стану морально-правової готовності працівників поліції до роботи з громадянами у сфері забезпечення прав і свобод людини.

Особистісно-формувальні завдання безпосередньо пов'язані $з$ прищепленням правоохоронцям у різних формах виховної роботи знань, умінь, цінностей та особистісних характеристик, що становлять морально-правову готовність до роботи з громадянами у сфері забезпечення прав i свобод людини. Посилаючись на працю В. Кіма, підкреслимо, що реалізація завдань такої роботи передбачає формування духовної та психологічної готовності захищати законні права й інтереси українського народу та держави, формування якостей громадянина-патріота; поваги до Конститу- ції та Законів України, свідомого виконання ними вимог Присяги працівника поліції; знань щодо положень Наказу МВС України «Про затвердження Правил етичної поведінки поліцейських», інших наказів і розпоряджень Міністерства внутрішніх справ України; високих моральних і професійно необхідних якостей поліцейського, свідомого ставлення до виконання службових обов'язків; почуття відповідальності й дисциплінованості; високої правової культури, прагнення постійно підвищувати професійну майстерність тощо [8, с. 39].

У результаті наукового пошуку все розмаїття завдань щодо формування моральноправової готовності працівників поліції до взаємодії з громадянами задля вирішення правоохоронних питань згруповано нами так:

- розвиток професійної активності, небайдужості до проблем громадян шляхом залучення до участі в різних формах виховної і волонтерської роботи;

- підвищення правосвідомості працівників на основі набуття досвіду застосування в змодельованих і реальних життєвих і професійних ситуаціях морально-правових знань і вмінь, розуміння основ законності та правопорядку;

- розвиток моральних професійно спрямованих якостей і характеристик особистості;

- формування загальної культури правоохоронців, пов'язаної з розумінням ієрархії правових і моральних цінностей у житті людини, зокрема й у професійній сфері, ціннісного ставлення до професії правоохоронця, здатності до застосування найвищих моральних норм у процесі здобуття освіти й подальшої професійної діяльності;

- засвоєння активної громадської позиції, формування суб'єктності фахівця на основі розвитку вмінь самостійно оцінювати й приймати рішення, що визначають стратегію поведінки та професійної діяльності працівника поліції з урахуванням громадянських, моральних, правових норм.

Зміст процесу формування моральноправової готовності працівників органів поліції до вирішення проблем громадян у сфері забезпечення прав і свобод людини складається з таких основних напрямів, які забезпечують той чи інший аспект різнобічного формування їхньої морально-правової готовності до служби в органах внутрішніх справ: громадянсько-патріотичне, моральне, політичне, правове, фізичне виховання, кожне з яких має свою специфіку. Ураховуючи складний і багатоаспектний характер процесу формування морально-правової готовності працівників органів поліції до вирішення проблем громадян у сфері 
забезпечення прав і свобод людини, ми здійснили його розподіл на низку етапів. Перший - адаптачійний - пов'язаний із допрофесійною підготовкою курсантів, а також адаптацією нових працівників на робочому місці, розвитком у них мотивації до самовдосконалення в питаннях формування морально-правової готовності до роботи в системі Національної поліції, передбачає ix призвичаювання в колективі, інтеграцію професійних цінностей і пріоритетів, правил і норм тощо. Другий етап - особистісно-розвивальний - забезпечує формування в поліцейських професійно важливих якостей, що становлять основу морально-правової готовності до служби в органах внутрішніх справ. На третьому етапі - професіоналізуючому - підготовки випускників до самостійної професійної діяльності - виховні впливи зосереджені на відпрацюванні ними знань і вмінь, засвоєнні соціальних і професійних ролей майбутньої службової діяльності на основі найвищих еталонів морально-правової готовності фахівців.

Загалом зазначимо, що теоретичний аналіз проблеми та вивчення наявного стану виховної роботи з формування моральноправової готовності поліцейських дають підстави визначити досліджений нами напрям виховної роботи як створення умов і режиму життєдіяльності особистості в умовах того чи іншого виду професійної підготовки чи підвищення кваліфікації, які б забезпечували закріплення та розвиток у різних формах виховної діяльності морально-правових знань поліцейських, формування в них загальної культури, пов'язаної з розумінням ієрархії правових і моральних цінностей у житті людини, зокрема й у професійній сфері; ціннісного ставлення до професії правоохоронця; здатності до застосування найвищих моральних норм у процесі професіоналізації та подальшої професійної діяльності; гуманістичної спрямованості особистості; умінь самостійно оцінювати й приймати рішення, що визначають стратегію поведінки та професійної діяльності правоохоронця з урахуванням громадянських, моральних, правових норм.

Процес формування морально-правової готовності працівників органів поліції до вирішення проблем громадян у сфері забезпечення прав і свобод людини має здійснюватися комплексно, у контексті висвітлення сучасних тенденцій розвитку правоохоронної сфери в Україні, нових цілей і завдань виховної роботи зі слухачами, курсантами та службовим складом органів поліції в процесі первинної професійної підготовки, післядипломної освіти, службової підготовки.
Процес формування морально-правової готовності працівників органів поліції до правоохоронної роботи 3 громадянами має подвійну спрямованість, забезпечуючи, 3 одного боку особистісний розвиток правоохоронця, з іншого - розширюючи та збагачуючи правові знання й досвід професійноправої взаємодії з громадою, і відбувається в єдності та взаємопідпорядкуванні всього процесу загальній виховній меті. Зазначена мета полягає у створенні умов i режиму освіти й самонавчання особистості поліцейського, які повсякчас забезпечували б збагачення морально-правових знань, формування гуманістичних особистісних цінностей у професійній сфері, засвоєння ціннісного ставлення до професії правоохоронця загалом і такого виду діяльності, як взаємодія з населенням; підвищення професійної мотивації і здатності до реалізації моральних норм у професійній діяльності тощо.

\section{Висновки}

Формування морально-правової готовності працівників органів Національної поліції України до роботи з громадянами передбачає вирішення адміністративнорегуляційних та особистісно-формувальних завдань. Перша група завдань спрямована на вирішення питань адміністративно-правового регулювання процесу організації підготовки поліцейських, найважливішим із яких, безумовно, є підготовка всіх суб'єктів системи МBC до роботи з формування морально-правової готовності слухачів, курсантів, працівників на основі глибокого розуміння наявних умов, можливостей і шляхів спільної, узгодженої реалізації такої діяльності, оцінки реального стану морально-правової вихованості майбутніх і молодих фахівців у зіставленні з тими вимогами, які висуває до цього фахівця міжнародне й вітчизняне законодавство, а також безпосередньо громада. Виховні завдання безпосередньо пов'язані з формуванням у правоохоронців у різних формах виховної роботи знань, умінь, цінностей та особистісних характеристик, що становлять морально-правову готовність поліцейських до роботи з населенням.

Зміст виховного процесу щодо формування морально-правової готовності працівників органів Національної поліції України складається з основних напрямів підготовки (громадянсько-патріотичний, морально-ціннісний, політичний, правовий, фізичний), кожен із яких має свою специфіку, забезпечуючи той чи інший аспект різнобічного формування морально-правової готовності поліцейських до роботи у сфері захисту прав і свобод громадян. 
Перспективним напрямом подальших досліджень порушеної проблеми є розроблення форм і методів підвищення рівня морально-правової готовності працівників органів Національної поліції України до роботи з громадянами у сфері забезпечення прав і свобод людини.

\section{Список використаних джерел:}

1. Теоретико-прикладні засади конструктивної взаємодії поліції і населення в соціумі : монографія / В.В. Середа, Р.І. Благута, О.М. Балинська, З.Я. Ковальчук, О.М. Ковбич, Л.Й. Гуменюк та ін. ; за заг. ред. З.Р. Кісіль. Львів : ЛьвДУВС, 2017. $600 \mathrm{c}$.

2. Посохова Я.С. Психологічні особливості професійно-правової ідентичності правоохоронців (на прикладі поліцейських підрозділів України) : автореф. дис. ... канд. психол. наук : 19.00.06 / Харків. нац. ун-т внутр. справ. Харків, 2016. $23 \mathrm{c}$.

3. Кісіль 3.Р. Адміністративно-правовий статус працівника міліції як фактор протидії професійній деформації. Південноукраїнський правничий часопис. 2008. № 2. С. 123-126.

4. Литвин В.В. Формування та розвиток професійної компетентності патрульного поліцейського. Науковий вісник Національної академії внутрішніх справ. 2018. № 1. С. 277-288.

5. Сокуренко В.В. Особливості професійного навчання працівників поліції в сучасних умовах: закордонний досвід та можливості його використання в Україні. Особливості підготовки полічейських в умовах реформування системи МВС України : збірник матеріалів I Міжнар. наук.-практ. конф. (м. Харків, 20 трав. 2016 р.) / МВС України, Департамент патрул. поліції України ; Харків. нац. ун-т внутр. справ,
Каф. спец. фіз. підготовки. Харків : ХНУВС 2016. С. $8-13$

6. Яровий С.М. Організаційно-правове забезпечення виховної роботи в закладах освіти : дис. ... канд. юрид. наук : 12.00 .07 / МВС України Національний університет внутрішніх справ. Харків, 2003. $204 \mathrm{c}$.

7. Ортинський В.Л. Педагогіка вищої школи : навчальний посібник для студентів вищих навчальних закладів. Київ : Центр учбової літератури, 2009. 472 c.

8. Кім В.Р. Цільовий компонент виховної роботи з формування морально-правової готовності курсантів у ВНЗ системи МВС України Соиіальна педагогіка: теорія та практика. 2014 № 1. C. $36-42$.

9. Про Національну поліцію : Закон України від 2 липня 2015 року № 580-VIII.

10. Про затвердження Положення про організацію первинної професійної підготовки поліщейських, яких вперше прийнято на службу в поліції МВС України; Наказ, Положення, Довідка [...] від 16.02.2016 № 105 URL: https://zakon.rada.gov.ua/ laws/show/z0576-16\#Text.

11. Про затвердження Порядку добору, направлення та зарахування кандидатів на навчання до закладів вищої освіти із специфічними умовами навчання, які здійснюють підготовку кадрів для Міністерства внутрішніх справ України і Національної поліції України, та вищого військового навчального закладу Національної гвардії України від 15.04.2016 № 315. URL: https:// zakon.rada.gov.ua/laws/show/z0668-16\#Text.

12. Про затвердження Змін до Положення про вищі навчальні заклади МВС, затвердженого Наказом МВС України від 14 лютого 2008 року № 62, зареєстрованого в Міністерстві [...] МВС України; Наказ від 15.10.2013 № 982. URL: https:/ zakon.rada.gov.ua/laws/show/z1892-13\#Text.

Andrii Tanko. Moral and legal readiness of the National Police of Ukraine officers to solve the problems of citizens in the field of ensuring rights and rights

The article substantiates the need to improve the moral and legal readiness of employees of the National Police of Ukraine to work with citizens in the context of increasing the requirements for the level of professional competence of employees of the National Police as an important subject of human rights and freedoms in Ukraine.

Based on the analysis of legislative acts, legal literature, it is proved that the consideration of the process of formation of moral and legal readiness of police officers to solve problems of citizens in the field of human rights and freedoms should be comprehensive, in the context of current trends in law enforcement in Ukraine, new goals and tasks of educational work with students, cadets and police personnel in the process of initial training, postgraduate education, training, which will ensure the integrity of coverage of the problem, will trace the unity and subordination of the general educational purpose of different types of training of the National Police of Ukraine.

It is established that the process of formation of moral and legal readiness of police officers to laze enforcement work with citizens has a dual focus, providing, on the one hand, personal development of law enforcement, on the other - expanding and enriching legal knowledge and experience of professional and legal interaction with the community. The purpose of training a police officer to solve human rights problems is to create conditions and regime of education and self-education of the specialist, which would always provide enrichment of moral and legal knowledge, formation of humanistic personal values in the professional sphere, mastering the values of law enforcement in general and such activities, as interaction with the population; increasing professional motivation and ability to implement high moral standards in professional activities.

Key words: human rights and freedoms, community work, moral and legal readiness, police officers. 